\title{
Matching synaptic type with postsynaptic firing class shapes the encoding of either stimulus rate or rate change
}

\author{
Ashutosh Mohan ${ }^{1 *}$, Mark D McDonnell ${ }^{2}$, Christian Stricker ${ }^{1,3}$ \\ From Twentieth Annual Computational Neuroscience Meeting: CNS*2011 \\ Stockholm, Sweden. 23-28 July 2011
}

The synergy between synaptic and postsynaptic firing dynamics in shaping neuronal encoding has not been explored. We show that by matching short-term synaptic dynamics with postsynaptic firing class, either stimulus rate or a rate change are encoded. The result may be relevant to understand the function of cortical microcircuits.

Short-term synaptic dynamics and firing dynamics of neurons can each be classified into two types. In shortterm plasticity, type 1 synapses show release-dependent depression and constant rate of recovery. They appear to encode a stimulus rate change. Type 2 synapses show release-independent depression and faster recovery at higher stimulus frequencies. They can follow the stimulus rate [1]. Postsynaptic firing characteristics conform either to class 1 or 2 on the basis of phase-reset curves
(PRCs) [2]. Class 1 neurons can fire at arbitrarily low frequencies and do not exhibit spike frequency adaptation. Class 2 neurons exhibit subthreshold oscillations and spike frequency adaption.

We investigate if different combinations of synaptic and postsynaptic dynamics can shape neuronal encoding.

Using NEURON, we simulated biophysically realistic cells with class 1 or 2 firing dynamics [3] that receive 2000 unsynchronized type 1 or 2 synaptic inputs [1]. When class 1 neurons are matched with type 2 synaptic inputs the average synaptic stimulus rate is encoded in the firing rate (Fig. 1A,1B). When class 2 neurons and type 1 inputs are matched, the rate change but not its magnitude is encoded (Fig. 1C,1D). For unmatched cases, rate and rate change are encoded to different

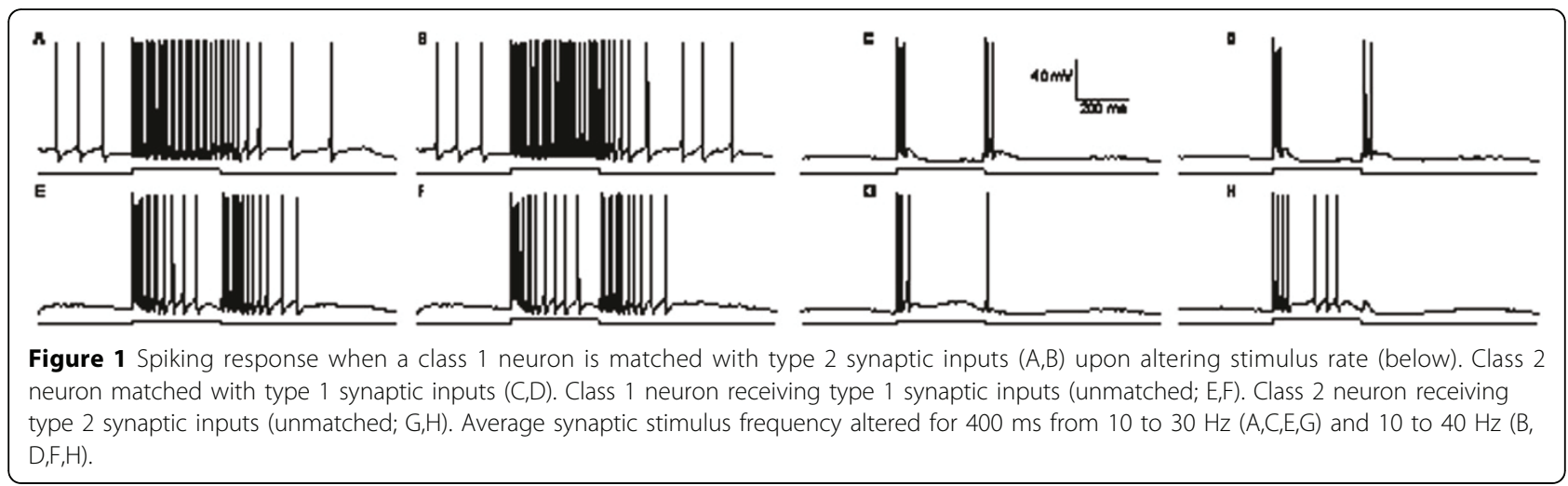

\footnotetext{
* Correspondence: ashutosh.mohan@anu.edu.au

'John Curtin School of Medical Research, Australian National University,

Canberra, ACT 2601, Australia

Full list of author information is available at the end of the article
}

(c) 2011 Mohan et al; licensee BioMed Central Ltd. This is an open access article distributed under the terms of the Creative Commons 
extents (Fig. 1E-1H), suggesting both synaptic and postsynaptic dynamics shape encoding.

Spiny stellate cells in the layer IV microcircuit preferentially receive inputs from type 1 synapses while star pyramidal neurons receive type 2 inputs [4]. Even though the PRC for these cell types have not been characterized yet, our results pinpoint the possibility that in layer IV rate changes are encoded in the network of spiny stellate and stimulus rate in that of star pyramidal cells.

\section{Acknowledgements}

Mark D. McDonnell is supported by the Australian Research Council (grant DP1093425).

\section{Author details}

'John Curtin School of Medical Research, Australian National University, Canberra, ACT 2601, Australia. ${ }^{2}$ Institute for Telecommunication Research, University of South Australia, Mawson Lakes, SA 5095, Australia. ${ }^{3}$ ANU

Medical School, Australian National University, Canberra, ACT 2601, Australia.

Published: 18 July 2011

\section{References}

1. Fuhrmann G, Cowan A, Segev I, Tsodyks M, Stricker C: Multiple mechanisms govern the dynamics of depression at neocortical synapses of young rats. J Physiol 2004, 557:415-438

2. Ermentrout B: Type I membranes, phase resetting curves, and synchrony. Neural Comput 1996, 8:979-1001.

3. Stiefel KM, Gutkin BS, Sejnowski TJ: The effects of cholinergic neuromodulation on neuronal phase-response curves of modeled cortical neurons. J Comput Neurosci 2009, 26:289-301.

4. Cowan Al, Stricker C: Functional connectivity in layer IV local excitatory circuits of rat somatosensory cortex. J Neurophysiol 2004, 557:415-438.

doi:10.1186/1471-2202-12-S1-P321

Cite this article as: Mohan et al:: Matching synaptic type with postsynaptic firing class shapes the encoding of either stimulus rate or rate change. BMC Neuroscience 2011 12(Suppl 1):P321.

\section{Submit your next manuscript to BioMed Central} and take full advantage of:

- Convenient online submission

- Thorough peer review

- No space constraints or color figure charges

- Immediate publication on acceptance

- Inclusion in PubMed, CAS, Scopus and Google Scholar

- Research which is freely available for redistribution

Submit your manuscript at www.biomedcentral com/submit 